\title{
Potential applications of microRNA profiling to forensic investigations
}

\author{
CLAIRE L. GLYNN \\ Department of Forensic Science, Henry C. Lee College of Criminal Justice and Forensic Sciences, University of New Haven, \\ West Haven, Connecticut 06516, USA
}

\begin{abstract}
Within the forensic science community, there is a continued push to develop novel tools to aid in criminal investigations. microRNA (miRNA) analysis has been the focus of many researcher's attention in the biomedical field since its discovery in 1993; however, the forensic application of miRNA analysis has only been suggested within the last 10 years and has been gaining considerable traction recently. The primary focus of the forensic application of miRNA analysis has been on body fluid identification to provide confirmatory universal analysis of unknown biological stains obtained from crime scenes or evidence items. There are, however, other forensic applications of miRNA profiling that have shown potential, yet are largely understudied, and warrant further investigation such as organ tissue identification, donor age estimation, and more. This review paper aims to evaluate the current literature and future potential of miRNA analysis within the forensic science field.
\end{abstract}

Keywords: microRNA profiling; forensic science; body fluid identification; forensic investigations; organ tissue source identification

\section{INTRODUCTION}

microRNAs (miRNAs) are short, single-stranded, noncoding RNA molecules, typically 20-24 nt in length. The study of miRNAs began with the finding of their functional ability to regulate protein production in 1993 with the discovery of lin-4 by Lee et al. (1993). Seven years later, the second miRNA was discovered, let-7 (Pasquinelli et al. 2000), and miRNAs were subsequently established as a new class of riboregulators (Lagos-Quintana et al. 2001; Lau et al. 2001; Lee and Ambros 2001). Within the biomedical research community, miRNA analysis truly came to fruition when it was discovered that miRNAs play critical roles in a wide variety of biological and pathological processes, and that miRNAs were actually tissue-specific and could provide a signature of disease (Calin et al. 2002; Ambros 2004; Bartel 2004; Lu et al. 2005; Etheridge et al. 2011; Wegman and Krylov 2013). Since then there has been an explosion of interest in miRNAs and their diverse and wide-ranging capabilities within many disciplines of biological research. This research has mainly focused on clinical biological samples, such as various tissues (cancer vs. normal), cerebrospinal fluids, and cultured primary tissues. Comparatively, minimal research has focused on forensically relevant samples (e.g., body fluids, organ tissues, trace

Corresponding author: cglynn@newhaven.edu

Article is online at http://www.rnajournal.org/cgi/doi/10.1261/rna. 072173.119. deposits). The first suggestion of the forensic application of miRNAs was in 2009, when Hanson et al. (2009) suggested their potential for forensic body fluid identification (BFID). In the decade since, several researchers worldwide have investigated the potential for the forensic application of miRNAs. Despite the great promise miRNAs have shown in the last decade in terms of their forensic application, this field still remains very much in its infancy and has not yet been implemented in active forensic investigations or operational crime laboratory protocols. With the advancement of molecular methodologies and the sophistication of the techniques now used, miRNA profiling represents an ideal tool to supplement the forensic scientist's arsenal. Further studies and validation, however, are very much warranted, and required, in order to truly reveal the forensic potential of miRNA profiling, and certainly to withstand the scrutiny necessary for legal presentation in the courtroom.

\section{BODY FLUID IDENTIFICATION}

The identification of forensically relevant body fluids in a forensic investigation can provide important and probative

(c) 2020 Glynn This article is distributed exclusively by the RNA Society for the first 12 months after the full-issue publication date (see http:// rnajournal.cshlp.org/site/misc/terms.xhtml). After 12 months, it is available under a Creative Commons License (Attribution-NonCommercial 4.0 International), as described at http://creativecommons.org/ licenses/by-nc/4.0/. 
evidence. Unambiguously confirming the body fluid source of a DNA profile is critical in forensic investigations as it clarifies the circumstances of an act, aids in determining the sequence of events, confirms or refutes victims/ suspects/witness statements, and ultimately can provide linkages between victim/perpetrator/scene. Although there are both presumptive and confirmatory tests in routine practice for the commonly encountered forensically relevant body fluids (e.g., blood, semen, saliva, and urine), there are numerous limitations to these tests. Current BFID tests are based on chemical, enzymatic, or immunological reactions and typically have good sensitivity. However, their specificity is limited, with many tests presenting cross-reactivity with other body fluids, and they also produce a number of false positives (Virkler and Lednev 2009). Current tests, for the most part, are destructive to a sample, which is a major concern when dealing with already trace amounts of sample, and sufficient sample is required for subsequent DNA profiling to identify the donor of the body fluid. In addition, there are some body fluids, such as vaginal material and menstrual blood, which are greatly lacking in widely accepted protocols for their identification. Further to this, there is a great need for the development of a universal body fluid test, thereby eliminating the requirement to perform multiple individual body fluid tests, and having, instead, one test for them all.
Last, in an effort to streamline forensic biology work processes within operational crime laboratories, there is a need for the development of a method that also simultaneously contributes to the production of a DNA profile of the donor of the body fluid. Therefore, a method in which the sample preparation required for the body fluid test also provides DNA content for profiling would greatly improve the efficiency of the testing (see Fig. 1). In essence, the "ideal" forensic BFID test would be sensitive, specific, nondestructive, universal, and efficient.

Currently, there are significant efforts in the forensic science research field to develop novel methods for the identification of body fluids, to address the challenges currently faced. Previously, messenger RNA (mRNA) was thought to be a suitable candidate for the identification of body fluids. However, it was subsequently shown that mRNAs are susceptible to degradation and therefore are not always suitable for all forensically relevant samples-in particular, those samples that have been exposed to harsh environments (Hall and Ballantyne 2004; Setzer et al. 2008; Vennemann and Koppelkamm 2010; Haas et al. 2013; Hall et al. 2014). MiRNAs, however, contain a wealth of information and are significantly more robust (Lee et al. 1993; Ambros 2001; Winter et al. 2009) than their mRNA counterparts, because of their smaller size. The tissue specificity of miRNAs discovered in the biomedical field

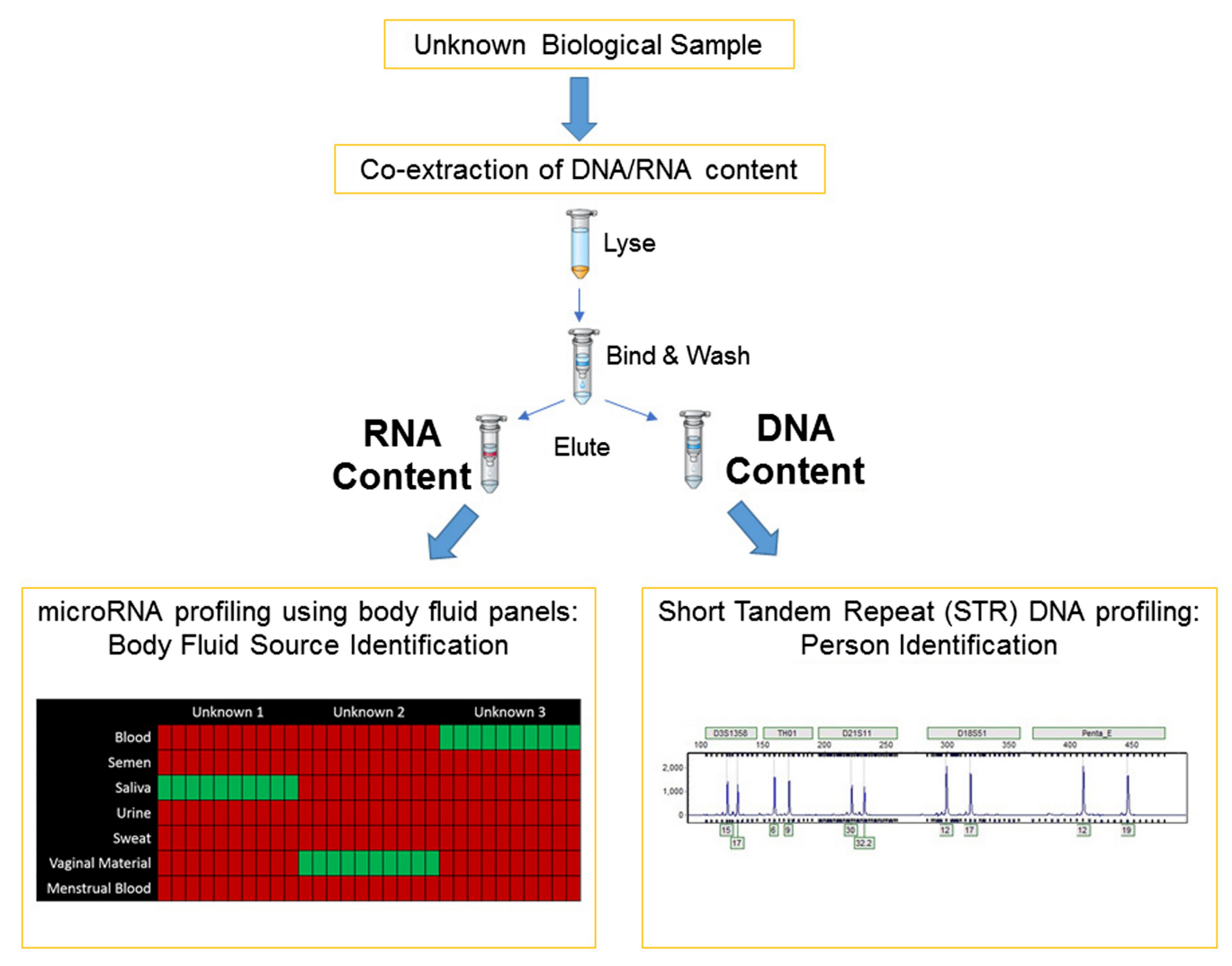

FIGURE 1. Workflow for universal microRNA body fluid identification with simultaneous DNA profiling. 
sparked the idea that miRNAs could be utilized as markers for body fluids in forensic investigations (Hanson et al. 2009; Courts and Madea 2010), whereby specific body fluids would have specific miRNA signatures/expression profiles. Furthermore, forensic samples are often minute traces, and therefore any test that consumes the sample poses the risk of not having enough sample remaining after testing in order to obtain a DNA profile. The total nucleic acid content, however, can be extracted from a sample by means of a coextraction, producing two fractions: the DNA content and the total RNA component. This allows efficient processing of forensic samples, with BFID and DNA profiling occurring in parallel (Bauer and Patzelt 2003; Alvarez et al. 2004; Bowden et al. 2011; van der Meer et al. 2013; Li et al. 2014; Watanabe et al. 2014). Further to this, a recent study reports the ability to detect miRNAs in DNA extracts obtained using commonly used forensic DNA extraction methods (e.g., QIAamp DNA Investigator Kit [QIAGEN]) without any modifications to the protocols (Lewis et al. 2019). This highlights the ease of implementation of miRNA profiling into current crime laboratory workflows, whereby separate RNA extraction or coextraction methods are not strictly necessary. Moreover, potential exists for miRNA profiling to be performed in cold case investigations, in which only DNA extracts remain from the original evidence item submitted.

Previous published studies reported promising results identifying differentially expressed miRNAs with great potential as novel biomarkers for forensic BFID (Hanson et al. 2009; Zubakov et al. 2010; Courts and Madea 2011; Wang et al. 2013; Sauer et al. 2016; Seashols-Williams et al. 2016;
Sirker et al. 2017; Mayes et al. 2018; O'Leary and Glynn 2018; Tian et al. 2018). In the small number of studies published in this area, however, there is little agreement between them, with only some miRNAs suggested as potential biomarkers for specific fluids overlapping between studies (see Table 1).

The first to explore the forensic application of miRNAs was Erin K. Hanson in 2009 (Hanson et al. 2009). At first, researchers aimed to discover miRNAs that are specific to one particular body fluid; however, research studies have been unsuccessful in this search thus far (Hanson et al. 2009; Zubakov et al. 2010; Courts and Madea 2011; Wang et al. 2013; Sauer et al. 2016; Seashols-Williams et al. 2016; Sirker et al. 2017; Mayes et al. 2018; Tian et al. 2018). However, Hanson et al. (2009) revealed nine miRNAs that were sufficiently differentially expressed to such a degree as to permit the identification of the particular body fluid. In addition, Hanson et al. (2009) revealed that as little as $50 \mathrm{pg}$ of total RNA was needed, highlighting its utility with minute forensic samples. Zubakov et al. (2010) screened a large set of 718 human miRNA markers in forensically relevant body fluids, using the most comprehensive microarray platform available at that time. The results identified a number of candidate miRNAs for each body fluid. However, upon further validation using reverse transcription quantitative polymerase chain reaction (RT-qPCR), only two miRNAs for blood and two for semen were suggested as suitable for future forensic applications. Furthermore, this study also revealed the time-wise stability of miRNAs over 1 year in ambient laboratory conditions and also the sensitivity of this technique, as reliable marker

TABLE 1. miRNAs identified in the literature as showing potential as a biomarker for individual body fluids

\begin{tabular}{|c|c|c|c|c|c|c|c|c|}
\hline Body fluid & $\begin{array}{l}\text { Mayes et al. } \\
\text { (2018) }\end{array}$ & $\begin{array}{l}\text { Sirker et al. } \\
\text { (2017) }\end{array}$ & $\begin{array}{l}\text { Seashols- } \\
\text { Williams } \\
\text { et al. (2016) }\end{array}$ & $\begin{array}{l}\text { Sauer et al. } \\
\text { (2016) }\end{array}$ & Wang et al. (2013) & $\begin{array}{l}\text { Courts and } \\
\text { Madea } \\
(2011)\end{array}$ & $\begin{array}{l}\text { Zubakov } \\
\text { et al. (2010) }\end{array}$ & $\begin{array}{l}\text { Hanson } \\
\text { et al. (2009) }\end{array}$ \\
\hline Venous blood & $\begin{array}{l}\text { miR-142-3p, } \\
\text { miR-451 }\end{array}$ & $\begin{array}{l}\text { miR-16, } \\
\text { miR-451 }\end{array}$ & miR-200b & $\begin{array}{l}\text { miR-144-3p, } \\
\text { miR-144-5p, } \\
\text { miR-451a }\end{array}$ & miR-16, miR-486 & $\begin{array}{l}\text { miR-126, } \\
\text { miR-150, } \\
\text { miR-451 }\end{array}$ & $\begin{array}{l}\text { miR-20a, } \\
\text { miR-106a, } \\
\text { miR-185, } \\
\text { miR-144 }\end{array}$ & $\begin{array}{l}\text { miR-16, } \\
\text { miR-451 }\end{array}$ \\
\hline Menstrual blood & $\begin{array}{l}\text { miR-141-3p, } \\
\text { miR-412-3p }\end{array}$ & $\begin{array}{l}\text { miR-185, } \\
\text { miR-412-3p }\end{array}$ & miR-200b & $\begin{array}{l}\text { miR-144-3p, } \\
\text { miR-144-5p, } \\
\text { miR-451a }\end{array}$ & miR-214 & - & $\begin{array}{l}\text { miR-144, } \\
\text { miR-185 }\end{array}$ & $\begin{array}{l}\text { miR-412, } \\
\text { miR-451 }\end{array}$ \\
\hline Semen & $\begin{array}{l}\text { miR-10b, } \\
\text { miR-891a }\end{array}$ & $\begin{array}{l}\text { miR-10b, } \\
\text { miR-943 }\end{array}$ & miR-891a & $\begin{array}{l}\text { miR-10a, } \\
\text { miR-10b, } \\
\text { miR-135a }\end{array}$ & miR-888, miR-891a & $\begin{array}{l}\text { miR-200, } \\
\text { miR-203, } \\
\text { miR-205 }\end{array}$ & $\begin{array}{l}\text { miR-10a, } \\
\text { miR-135a, } \\
\text { miR-507, } \\
\text { miR-943, } \\
\text { miR-891a }\end{array}$ & $\begin{array}{l}\text { miR-10b, } \\
\text { miR-135b }\end{array}$ \\
\hline Saliva & miR-205 & $\begin{array}{l}\text { miR-124, } \\
\text { miR-203, } \\
\text { miR-205 }\end{array}$ & miR-26b & - & miR-138 & - & $\begin{array}{l}\text { miR-208b, } \\
\text { miR-518c, } \\
\text { miR-583 }\end{array}$ & $\begin{array}{l}\text { miR-205, } \\
\text { miR-658 }\end{array}$ \\
\hline Vaginal material & - & $\begin{array}{l}\text { miR-1280, } \\
\text { miR-4286 }\end{array}$ & - & - & - & - & $\begin{array}{l}\text { miR-617, } \\
\text { miR-891a }\end{array}$ & $\begin{array}{l}\text { miR-124a, } \\
\text { miR-891a }\end{array}$ \\
\hline
\end{tabular}

$(-)$ Not studied/none found. 
detection was obtained with just picograms of starting material.

Wang et al. (2013) published a table illustrating some of the previous miRNA findings for particular body fluids in their research and other groups. Wang et al. performed an array that examined 754 human-specific miRNAs. Currently, the total count of discovered miRNAs that identify with Homo sapiens is 2700 according to the miRBase registry (release 22, accessed March 2019). Another database/registry, called MirGeneDB, compiled using primary high-throughput sequencing data, currently lists only 556 authentic human miRNA genes (Fromm et al. 2015). It could be suggested that perhaps a truly body fluid-specific miRNA has simply not yet been realized; however, by comparing both registries and considering only the authentic miRNAs, it appears that only a small number of new human miRNAs have been identified in the last decade. Therefore, it is unlikely that a new truly body fluidspecific miRNA that would have sufficient expression to enable quantification will be realized.

Although the discovery of truly specific miRNAs to individual body fluids would be of great benefit, it is reasonable to assume that the differential expression of multiple miRNA targets would provide BFID with sufficient accuracy. Sauer et al. (2016) published a comprehensive study using a thoroughly validated, state-of-the-art qPCR procedure and reported four miRNAs that were shown to be useful for differentiation. This study expanded further by using a decision algorithm to detect each of the five body fluids by using as few markers as possible to simplify the analysis procedure. The results, however, were not as discriminatory as expected, highlighting the fact that a panel of miRNAs for each body fluid is truly needed. RT-qPCR is currently the method of choice for differential expression analysis of individual miRNA targets. However, to ensure reliable detection and expression analysis of miRNAs for forensic BFID, it is essential that proper normalization strategies using endogenous controls are used. Sirker et al. (2017) identified four miRNAs as the most stably expressed across the set of samples and that, therefore, could act as potential endogenous controls. Further to this, five miRNAs were reported to be successful in the differentiation of six different cell types/ body fluids, using the previously identified endogenous controls to normalize the GPCR data. However, this study was not able to differentiate between venous and menstrual blood, which would be preferable for forensic applications. This study further highlighted the lack of exclusive marker specificity for one body fluid and a simple interpretation method. Both Sauer et al. (2016) and Sirker et al. (2017) stressed the importance, and benefits of, interlaboratory trials using a set of ubiquitously used markers to better assess the experimental approach and ultimately its suitability for forensic casework implementation.
Seashols-Williams et al. (2016) published the first report of forensically relevant body fluids subjected to nextgeneration sequencing (NGS) using the Illumina Hi-Seq platform. Also, Wang et al. (2016) reported small RNA sequencing of blood and saliva using the Ion Personal Genome Machine System (Wang et al. 2016). SeasholsWilliams et al. (2016) provided a very comprehensive and well-designed study that examined every step in the workflow. The authors identified a suitable RNA extraction procedure for forensically relevant body fluids and suitable endogenous controls for normalization in RT-qPCR, and they produced a large data set, with the consequent development of candidate miRNAs for further research. More recently, Dørum et al. (2019) applied whole miRNome massively parallel sequencing to six forensically relevant body fluids. Their findings were in agreement with those of Seashols-Williams et al., in particular with regard to the reference miRNA markers.

Once panels of miRNAs markers are identified and validated for BFID, it will be crucial to apply appropriate statistical methods to the data analysis. Validated multivariate statistical methods are certainly required for the analysis of differentially expressed miRNAs using RTqPCR. The $\triangle C T / \triangle \Delta C T$ methods are typically used in relative quantification (RQ) studies. Many of these studies report using one-way ANOVA and independent twosample t-tests to determine association and comparisons between individual body fluids and to assess significance (Courts and Madea 2011; Hanson and Ballantyne 2013; Li et al. 2017). Dørum et al. (2019) reported using partial least squares (PLS) and linear discriminant analysis (LDA) to predict body fluids and also identified a minimum number of miRNA markers that will still provide good prediction accuracy. Other statistical approaches have been applied, such as that of Hanson et al. (2014), who developed a quantitative statistical model using logistic regression to predict menstrual blood and reported a high, and measurable, degree of accuracy.

Although they are few, the previous research studies have highlighted the potential of miRNA markers for the identification of forensically relevant body fluids. However, further research is required to identify panels of unambiguous markers for each of the forensically relevant body fluids. Although the research studies discussed here contribute greatly to the growing body of knowledge on this topic, there is yet more research to be performed, however, and it must be assessed if results previously obtained are reproducible using different platforms and approaches. Further to this, some forensically relevant body fluids have been less extensively explored (e.g., vaginal fluid and menstrual blood). With further research, the potential of miRNAs for forensic BFID continues to grow. Should this novel method one day be implemented into routine casework, it will address current challenges encountered in body fluid testing by creating a sensitive, 
specific, universal test for BFID, which will also allow for the coextraction of both the DNA and RNA content in one process, thereby streamlining workflow processes and ultimately forensic practice.

\section{ORGAN TISSUE IDENTIFICATION}

Similar to BFID, the identification of certain internal organ tissues can yield valuable probative evidence in the investigation of a violent crime. During a violent act, internal organ tissue may be transferred from the victim to the perpetrator, to the weapon or innocuous item present, or to the location/scene at which the crime is being committed. Internal organ tissues may adhere to a bullet passing through a body or to a knife that has penetrated the skin. In certain circumstances, identifying the organ tissue source of a DNA profile obtained from an evidence item, such as a knife blade or a bullet, confirms the role that evidence item played in the crime being investigated. Furthermore, the ability to identify organ tissues in trace deposits of biological material located at scenes (e.g., in the plumbing or sewers of a building) can provide investigative leads to the possibility that the human remains have been removed to another location or the dismemberment or disposition of human remains at that location. Currently, there are no standard molecular operating procedures for organ tissue identification used in routine casework at operational crime laboratories. Investigators are limited to simply identifying the DNA profile of the donor of the specimen on the evidence item and can only suggest possible organ tissue sources of the DNA. If organ tissue identification was deemed crucial to an investigation, the sample would likely be sent out for cellular/histological analysis to either the Office of the Chief Medical Examiner (OCME) (only in the United States), State Pathologist, or to an external biological analysis company, where immunohistochemical analyses would likely be performed. Other traditional methods, using immunological and enzymatic processes, have previously been suggested as viable tools for this purpose, although none ever gained traction within the forensic science industry (Kimura et al. 1995; Takahama 1996; Seo et al. 1997; Takata et al. 2004). The most confounding limitation of all of the traditional methods is that they require a relatively large sample size that is in nearpristine condition. In forensic investigations, specimens are often minute in size and heavily degraded; therefore, these traditional methods are not ideally suited for forensic use.

In recent years, more molecular-based methods, such as mRNA and DNA methylation analysis, for organ tissue identification have been suggested as viable tools, with some researchers producing promising results (Hanson and Ballantyne 2017; van den Berge and Sijen 2017; Samsuwan et al. 2018). As miRNAs have shown great promise for BFID, it is logical to infer that same potential to their use for organ tissue identification, in particular because of the miRNA's robustness and ability to withstand degradation. Sauer et al. (2017) published the first report of the use of miRNA markers for the identification of brain, kidney, liver, lung, skin, heart muscle, and skeletal muscle. The researchers provided a comprehensive investigation by performing RT-qPCR of 15 preselected miRNAs on not just pristine samples, but also mixed, aged, and degraded samples. Further to this, the researchers generated samples from mock stabbings and shootings to ensure the robustness of this method to realistic forensic specimens. Although the study identified individual miRNAs that were differentially expressed and therefore showed potential as novel biomarkers for individual organ tissues, it was noted that multiple miRNAs or panels of miRNAs are advisable for the inference of certain tissues. The authors also note that further research should comprise larger sample sets and an expansion of the organs investigated, even suggesting organ subsections. However, this study provides a strong foundation from which further research into this novel application of miRNAs can now be explored.

\section{OTHER POTENTIAL FUTURE APPLICATIONS}

In the biomedical field, human aging is an area of great interest, in particular with regard to identifying diagnostic predictors of age-associated diseases, such as cancer. There is potential to translate the findings of biomedical research studies to forensic applications for estimating the age of a donor of a particular biological sample using miRNA analysis. Noren Hooten et al. (2010) profiled 800 miRNAs in both young ( $30 \mathrm{yr})$ and old ( $64 \mathrm{yr})$ cohorts, and reported that the majority of miRNAs decreased in abundance with age. This suggests that changes in miRNA expression could have potential as an indicator of the age of the donor. Similarly, determining the age of the actual stain-or as it is more commonly known, the time since deposition (TSD) - is often questioned in forensic investigations, as it could relate to the stain's relevance to the crime and also to determining the sequence of events. mRNAs were previously investigated as a potential tool for this purpose (Anderson et al. 2005); however, the wide range and instability of mRNA suggests this may not be an effective tool. One study reported three miRNAs (Mohammed et al. 2018) to steadily and significantly increase over time, whereas another (Alshehhi and Haddrill 2019) investigated the use of both mRNA and miRNA markers and reported that each marker exhibited a unique degradation profile over a 1-yr time period. Although these results are promising, further research is certainly required to assess the impact of environmental insults. Last, postmortem interval (PMI) estimation has recently been suggested as a novel application of miRNA 
analysis. PMI is defined as the period of time elapsed from the time of death. Currently, a variety of methods are used to estimate PMI (e.g., physical, physiochemical, biochemical, microbiological, entomological, and botanical processes) (Henssge and Madea 2007); however, none are absolute. The degradation of nucleic acids (both DNA and RNA) have been well-studied, and it recently has been suggested that nucleic acids could be ideal biomarkers of PMI (Di Nunno et al. 1998; Bauer et al. 2003; Liu et al. 2007; Sampaio-Silva et al. 2013; Scrivano et al. 2019). Both miRNAs and circulating RNAs (circRNAs) have shown satisfactory stability across a range of tissue types in the postmortem interval, highlighting that miRNAs are less susceptible to their environmental conditions and therefore suitable as stable reference genes (Tu et al. 2019). Although the results of this research are promising, there are many variables to be considered in estimating PMI, which are much more complex in real-life scenarios with humans than in laboratory conditions using animal models.

\section{POTENTIAL LIMITATIONS}

Should miRNA profiling be implemented into routine practice within forensic investigations, it is crucial that it is robust enough to handle the challenges that forensic samples typically bring (e.g., nonpristine environmentally damaged samples). Proteins, as well as nucleic acids, have all been found to degrade, lose conformation, and, subsequently, lose function over time. These processes are shown to be accelerated when exposed to various environmental insults (Pfeifer et al. 2005; Alaeddini et al. 2010). Some of these are, but not necessarily limited to, prolonged ultraviolet light exposure (Hall and Ballantyne 2004; Hall et al. 2014), excessive heat exposure (Lindahl and Nyberg 1974), water/moisture (Marrone and Ballantyne 2009, 2010), and various forms of chemical/enzymatic damage (Gates 2009). Various studies over the last decade have elucidated the nature of some of the damage mechanisms associated with biological evidence (Hall and Ballantyne 2004; Gates 2009; Marrone and Ballantyne 2009, 2010; Hall et al. 2014). DNA damage with regard to forensic specimens has been widely studied; various methods exist that attempt to repair various forms of DNA damage (Evans and Nichols 2008; Diegoli et al. 2012; Ambers et al. 2014; Robertson et al. 2014; Wallace 2014). Little is known, however, with regard to miRNA damage-in particular, with forensic specimens. There has been no published research to date that investigates the impact of damage on the RNA content of forensically relevant body fluids-more specifically the miRNA content-nor has there been any published research that explores the ability to "repair" the damaged RNA content of forensically relevant body fluids.
Uniformity and acceptance of methods across research studies has certainly presented limitations to date. The lack of agreement in the studies discussed previously (Table 1) could certainly be as a result of the variety of methods used across them. It is imperative that uniform and agreed-on methods are utilized on a global level, to ensure data obtained from different research groups or crime laboratories can be reliably compared. This includes agreement on the starting sample volume and concentration, the method of extraction and subsequent quantification, followed by the method of amplification and target analysis, and concluding with statistical/interpretation analysis to be performed. As miRNA research has progressed in the biomedical field, the RT-qPCR technique has become the gold standard for the analysis of individual miRNA targets, because of its ease of use and the robustness of the technique (Ach et al. 2008; Zubakov et al. 2010; Omelia et al. 2013; Sauer et al. 2016). NGS, however, has recently gained widespread attention for miRNA analysis. NGS for small RNAs allows the sequencing of small RNA species with unprecedented sensitivity and dynamic range. It is possible to discover novel miRNAs and also examine differential expression of all small RNAs in a sample. It has been suggested that NGS platforms will be standard instrumentation in crime laboratories in the future, as the advantages are many, in addition to their modes of applications within the forensic science discipline. As a result, all available NGS platforms must be investigated and compared to ensure the most appropriate platform is implemented. As stated previously, the ultimate goal is to identify panels of miRNAs for each individual body fluid to be used for identification; therefore, RT-qPCR may not be the ideal approach as multiple multiplexes and consumption of the sample would be required. NGS, although costly, would provide a more comprehensive, yet streamlined approach, because of its multiplexing nature and the ease of interrogating the whole or a large subset of the miRNAome.

Last, it is the author's opinion that there are three further reasons that contribute to keeping the forensic application of miRNAs from progressing to the level it deserves. First, there is a limited amount of funding provided for forensic science research applications, with novel research associated with forensic DNA profiling for person identification purposes often taking precedence over RNA profiling applications. Second, the required expertise in the area of miRNA analysis is predominantly focused in the biomedical/clinical field. Until sufficient funding is provided to the RNA-based forensic science discipline, however, it remains difficult to attract talented researchers to contribute to fields of study such as this. Last, the lack of commercially available kits and reagents designed specifically for forensic use is a further impediment to the implementation of miRNA and other RNA technologies in forensic casework applications. 


\section{CONCLUSION}

Although microRNA expression analysis is being widely explored the world over, this exploration has focused predominantly on its application to the biomedical/cancer research field. To truly reveal the full potential of miRNAs within the forensic field, it is crucial to unravel the molecular complexities of the samples at hand. The implementation of miRNA analysis into the forensic workflow as described above would serve to address several challenges currently faced by forensic scientists. By being able to establish robust performance under adverse conditions it allows for the reliable access to information that was not previously possible. It is time to move the state of the art forward, by addressing current challenges with new tools, thus allowing forensic scientists to harvest more layers of information from biological evidence. As mentioned previously, the forensic application of microRNA analysis is only just being realized. As a result, published research in this area is limited, yet growing. With the diverse array of forensic applications for miRNA analysis it is possible to pioneer novel approaches to physical evidence. In forensic science, methods that once seemed state-of-the-art, now are becoming antiquated. It is crucial that researchers work toward developing techniques for use in forensic investigations that produce results in record time, providing higher powers of discrimination, and that are sufficiently robust to gain acceptance by both the scientific community and, of course, the courtroom.

\section{REFERENCES}

Ach RA, Wang H, Curry B. 2008. Measuring microRNAs: comparisons of microarray and quantitative PCR measurements, and of different total RNA prep methods. BMC Biotechnol 8: 69. doi:10.1186/ 1472-6750-8-69

Alaeddini R, Walsh SJ, Abbas A. 2010. Forensic implications of genetic analyses from degraded DN-a review. Forensic Sci Int Genet 4: 148-157. doi:10.1016/j.fsigen.2009.09.007

Alshehhi S, Haddrill PR. 2019. Estimating time since deposition using quantification of RNA degradation in body fluid-specific markers. Forensic Sci Int 298: 58-63. doi:10.1016/j.forsciint.2019.02.046

Alvarez M, Juusola J, Ballantyne J. 2004. An mRNA and DNA co-isolation method for forensic casework samples. Anal Biochem 335: 289-298. doi:10.1016/j.ab.2004.09.002

Ambers A, Turnbough M, Benjamin R, King J, Budowle B. 2014. Assessment of the role of DNA repair in damaged forensic samples. Int J Legal Med 128: 913-921. doi:10.1007/s00414-0141003-3

Ambros V. 2001. microRNAs: tiny regulators with great potential. Cell 107: 823-826. doi:10.1016/S0092-8674(01)00616-X

Ambros V. 2004. The functions of animal microRNAs. Nature 431: 350-355. doi:10.1038/nature02871

Anderson S, Howard B, Hobbs GR, Bishop CP. 2005. A method for determining the age of a bloodstain. Forensic Sci Int 148: 37-45. doi:10.1016/j.forsciint.2004.04.071

Bartel DP. 2004. MicroRNAs: genomics, biogenesis, mechanism, and function. Cell 116: 281-297. doi:10.1016/S0092-8674(04)00045-5
Bauer M, Patzelt D. 2003. A method for simultaneous RNA and DNA isolation from dried blood and semen stains. Forensic Sci Int 136: 76-78. doi:10.1016/S0379-0738(03)00219-6

Bauer M, Gramlich I, Polzin S, Patzelt D. 2003. Quantification of mRNA degradation as possible indicator of postmortem interval-a pilot study. Leg Med (Tokyo) 5: 220-227. doi:10.1016/j.legalmed .2003.08.001

Bowden A, Fleming R, Harbison S. 2011. A method for DNA and RNA co-extraction for use on forensic samples using the Promega DNA IQ system. Forensic Sci Int Genet 5: 64-68. doi:10.1016/j.fsigen 2009.11.007

Calin GA, Dumitru CD, Shimizu M, Bichi R, Zupo S, Noch E, Aldler H, Rattan S, Keating M, Rai K, et al. 2002. Frequent deletions and down-regulation of micro-RNA genes miR15 and miR16 at $13 q 14$ in chronic lymphocytic leukemia. Proc Natl Acad Sci 99: 15524-15529. doi:10.1073/pnas.242606799

Courts C, Madea B. 2010. Micro-RNA-a potential for forensic science? Forensic Sci Int 203: 106-111. doi:10.1016/j.forsciint 2010.07.002

Courts C, Madea B. 2011. Specific micro-RNA signatures for the detection of saliva and blood in forensic body-fluid identification. J Forensic Sci 56: 1464-1470. doi:10.1111/j.1556-4029.2011 .01894.x

Diegoli TM, Farr M, Cromartie C, Coble MD, Bille TW. 2012. An optimized protocol for forensic application of the PreCR Repair Mix to multiplex STR amplification of UV-damaged DNA. Forensic Sci Int Genet 6: 498-503. doi:10.1016/j.fsigen.2011.09.003

Di Nunno NR, Costantinides F, Bernasconi P, Bottin C, Melato M. 1998. Is flow cytometric evaluation of DNA degradation a reliable method to investigate the early postmortem period? Am J Forensic Med Pathol 19: 50-53. doi:10.1097/00000433199803000-00008

Dørum G, Ingold S, Hanson E, Ballantyne J, Russo G, Aluri S, Snipen L, Haas C. 2019. Predicting the origin of stains from whole miRNome massively parallel sequencing data. Forensic Sci Int Genet 40: 131-139. doi:10.1016/j.fsigen.2019.02.015

Etheridge A, Lee I, Hood L, Galas D, Wang K. 2011. Extracellular microRNA: a new source of biomarkers. Mutat Res 717: 85-90. doi:10.1016/j.mrfmmm.2011.03.004

Evans TC, Nichols NM. 2008. DNA repair enzymes. Curr Protoc Mol Biol 84: 3.9.1-3.9.12. doi:10.1002/0471142727.mb0309s84

Fromm B, Billipp T, Peck LE, Johansen M, Tarver JE, King BL, Newcomb JM, Sempere LF, Flatmark K, Hovig E, et al. 2015. A uniform system for the annotation of vertebrate microRNA genes and the evolution of the human microRNAome. Annu Rev Genet 49: 213-242. doi:10.1146/annurev-genet-120213-092023

Gates KS. 2009. An overview of chemical processes that damage cellular DNA: spontaneous hydrolysis, alkylation, and reactions with radicals. Chem Res Toxicol 22: 1747-1760. doi:10.1021/ tx900242k

Haas C, Hanson E, Ballantyne J. 2013. mRNA and microRNA for body fluid identification. In Encyclopedia of forensic sciences, pp. 402408.

Hall A, Ballantyne J. 2004. Characterization of UVC-induced DNA damage in bloodstains: forensic implications. Anal Bioanal Chem 380: 72-83. doi:10.1007/s00216-004-2681-3

Hall A, Sims LM, Ballantyne J. 2014. Assessment of DNA damage induced by terrestrial UV irradiation of dried bloodstains: forensic implications. Forensic Sci Int Genet 8: 24-32. doi:10.1016/j .fsigen.2013.06.010

Hanson EK, Ballantyne J. 2013. Circulating microRNA for the identification of forensically relevant body fluids. Methods Mol Biol 1024: 221-234. doi:10.1007/978-1-62703-453-1_18

Hanson E, Ballantyne J. 2017. Human organ tissue identification by targeted RNA deep sequencing to aid the investigation 
of traumatic injury. Genes (Basel) 8: 319. doi:10.3390/ genes 8110319

Hanson EK, Lubenow H, Ballantyne J. 2009. Identification of forensically relevant body fluids using a panel of differentially expressed microRNAs. Anal Biochem 387: 303-314. doi:10.1016/j.ab.2009 .01 .037

Hanson EK, Mirza M, Rekab K, Ballantyne J. 2014. The identification of menstrual blood in forensic samples by logistic regression modeling of miRNA expression. Electrophoresis 35: 3087-3095. doi:10 .1002/elps.201400171

Henssge C, Madea B. 2007. Estimation of the time since death. Forensic Sci Int 165: 182-184. doi:10.1016/j.forsciint.2006.05.017

Kimura A, Ikeda H, Yasuda S, Yamaguchi K, Tsuji T. 1995. Brain tissue identification based on myosin heavy chain isoforms. Int $\mathrm{J}$ Legal Med 107: 193-196. doi:10.1007/BF01428404

Lagos-Quintana M, Rauhut R, Lendeckel W, Tuschl T. 2001. Identification of novel genes coding for small expressed RNAs. Science 294: 853-858. doi:10.1126/science.1064921

Lau NC, Lim LP, Weinstein EG, Bartel DP. 2001. An abundant class of tiny RNAs with probable regulatory roles in Caenorhabditis elegans. Science 294: 858-862. doi:10.1126/science.1065062

Lee RC, Ambros V. 2001. An extensive class of small RNAs in Caenorhabditis elegans. Science 294: 862-864. doi:10.1126/sci ence.1065329

Lee RC, Feinbaum RL, Ambros V. 1993. The C. elegans heterochronic gene lin-4 encodes small RNAs with antisense complementarity to lin-14. Cell 75: 843-854. doi:10.1016/0092-8674(93)90529-Y

Lewis CA, Layne TR, Seashols-Williams SJ. 2019. Detection of microRNAs in DNA extractions for forensic biological source identification. J Forensic Sci 64: 1823-1830. doi:10.1111/1556-4029 14070

Li Y, Zhang J, Wei W, Wang Z, Prinz M, Hou Y. 2014. A strategy for coanalysis of microRNAs and DNA. Forensic Sci Int Genet 12: 24-29. doi:10.1016/j.fsigen.2014.04.011

Li Z, Bai P, Peng D, Wang H, Guo Y, Jiang Y, He W, Tian H, Yang Y, Huang $Y$, et al. 2017. Screening and confirmation of microRNA markers for distinguishing between menstrual and peripheral blood. Forensic Sci Int Genet 30: 24-33. doi:10.1016/j.fsigen .2017.05.012

Lindahl T, Nyberg B. 1974. Heat-induced deamination of cytosine residues in deoxyribonucleic acid. Biochemistry 13: 3405-3410. doi:10.1021/bi00713a035

Liu L, Shu X, Ren L, Zhou H, Li Y, Liu W, Zhu C, Liu L. 2007. Determination of the early time of death by computerized image analysis of DNA degradation: which is the best quantitative indicator of DNA degradation? J Huazhong Univ Sci Technolog Med Sci 27: 362-366. doi:10.1007/s11596-007-0404-7

Lu J, Getz G, Miska EA, Alvarez-Saavedra E, Lamb J, Peck D, SweetCordero A, Ebert BL, Mak RH, Ferrando AA, et al. 2005. MicroRNA expression profiles classify human cancers. Nature 435: 834-838. doi:10.1038/nature03702

Marrone A, Ballantyne J. 2009. Changes in dry state hemoglobin over time do not increase the potential for oxidative DNA damage in dried blood. PLoS One 4: e5110. doi:10.1371/journal.pone .0005110

Marrone A, Ballantyne J. 2010. Hydrolysis of DNA and its molecular components in the dry state. Forensic Sci Int Genet 4: 168-177. doi:10.1016/j.fsigen.2009.08.007

Mayes C, Seashols-Williams S, Hughes-Stamm S. 2018. A capillary electrophoresis method for identifying forensically relevant body fluids using miRNAs. Leg Med (Tokyo) 30: 1-4. doi:10.1016/j .legalmed.2017.10.013

Mohammed AT, Khalil SR, Ali HA, Awad A. 2018. Validation of mRNA and microRNA profiling as tools in QPCR for estimation of the age of bloodstains. Life Sci J 15: 1-7.
Noren Hooten N, Abdelmohsen K, Gorospe M, Ejiogu N, Zonderman AB, Evans MK. 2010. microRNA expression patterns reveal differential expression of target genes with age. PLoS One 5: e10724. doi:10.1371/journal.pone.0010724

O'Leary KR, Glynn CL. 2018. Investigating the isolation and amplification of microRNAs for forensic body fluid identification. MicroRNA 7: 187-194. doi:10.2174/2211536607666180430153821

Omelia EJ, Uchimoto ML, Williams G. 2013. Quantitative PCR analysis of blood- and saliva-specific microRNA markers following solidphase DNA extraction. Anal Biochem 435: 120-122. doi:10 .1016/j.ab.2012.12.024

Pasquinelli AE, Reinhart BJ, Slack F, Martindale MQ, Kuroda MI, Maller B, Hayward DC, Ball EE, Degnan B, Muller P, et al. 2000. Conservation of the sequence and temporal expression of let-7 heterochronic regulatory RNA. Nature 408: 86-89. doi:10.1038/ 35040556

Pfeifer GP, You YH, Besaratinia A. 2005. Mutations induced by ultraviolet light. Mutat Res 571: 19-31. doi:10.1016/j.mrfmmm.2004.06 .057

Robertson JM, Dineen SM, Scott KA, Lucyshyn J, Saeed M, Murphy DL, Schweighardt AJ, Meiklejohn KA. 2014. Assessing PreCR repair enzymes for restoration of STR profiles from artificially degraded DNA for human identification. Forensic Sci Int Genet 12: 168-180. doi:10.1016/j.fsigen.2014.05.011

Sampaio-Silva F, Magalhães T, Carvalho F, Dinis-Oliveira RJ, Silvestre R. 2013. Profiling of RNA degradation for estimation of post morterm [sic] interval. PLoS One 8: e56507. doi:10.1371/jour nal.pone.0056507

Samsuwan J, Muangsub T, Yanatatsaneejit P, Mutirangura A, Kitkumthorn N. 2018. Combined bisulfite restriction analysis for brain tissue identification. Forensic Sci Int 286: 42-45. doi:10 .1016/j.forsciint.2018.02.032

Sauer E, Reinke AK, Courts C. 2016. Differentiation of five body fluids from forensic samples by expression analysis of four microRNAs using quantitative PCR. Forensic Sci Int Genet 22: 89-99. doi:10 .1016/j.fsigen.2016.01.018

Sauer E, Extra A, Cachée P, Courts C. 2017. Identification of organ tissue types and skin from forensic samples by microRNA expression analysis. Forensic Sci Int Genet 28: 99-110. doi:10.1016/j.fsigen .2017.02.002

Scrivano S, Sanavio M, Tozzo P, Caenazzo L. 2019. Analysis of RNA in the estimation of post-mortem interval: a review of current evidence. Int J Legal Med. 133: 1629-1640. doi:10.1007/s00414019-02125-x

Seashols-Williams S, Lewis C, Calloway C, Peace N, Harrison A, HayesNash C, Fleming S, Wu Q, Zehner ZE. 2016. High-throughput miRNA sequencing and identification of biomarkers for forensically relevant biological fluids. Electrophoresis 37: 2780-2788. doi:10.1002/elps.201600258

Seo Y, Kakizaki E, Takahama K. 1997. A sandwich enzyme immunoassay for brain S-100 protein and its forensic application. Forensic Sci Int 87: 145-154. doi:10.1016/S0379-0738(97)00049-2

Setzer M, Juusola J, Ballantyne J. 2008. Recovery and stability of RNA in vaginal swabs and blood, semen, and saliva stains. J Forensic Sci 53: 296-305. doi:10.1111/j.1556-4029.2007.00652.x

Sirker M, Fimmers R, Schneider PM, Gomes I. 2017. Evaluating the forensic application of 19 target microRNAs as biomarkers in body fluid and tissue identification. Forensic Sci Int Genet 27: 41-49. doi:10.1016/j.fsigen.2016.11.012

Takahama K. 1996. Forensic application of organ-specific antigens. Forensic Sci Int 80: 63-69. doi:10.1016/0379-0738(96)01928-7

Takata T, Miyaishi S, Kitao T, Ishizu H. 2004. Identification of human brain from a tissue fragment by detection of neurofilament proteins. Forensic Sci Int 144: 1-6. doi:10.1016/j.forsciint.2004.01 .020 
Tian H, Lv M, Li Z, Peng D, Tan Y, Wang H, Li Q, Li F, Liang W. 2018. Semen-specific miRNAs: suitable for the distinction of infertile semen in the body fluid identification? Forensic Sci Int Genet 33: 161-167. doi:10.1016/j.fsigen.2017.12.010

Tu C, Du T, Ye X, Shao C, Xie J, Shen Y. 2019. Using miRNAs and circRNAs to estimate PMI in advanced stage. Leg Med (Tokyo) 38: 51-57. doi:10.1016/j.legalmed.2019.04.002

van den Berge M, Sijen T. 2017. Extended specificity studies of mRNA assays used to infer human organ tissues and body fluids. Electrophoresis 38: 3155-3160. doi:10.1002/elps.201700 241

van der Meer D, Uchimoto ML, Williams G. 2013. Simultaneous analysis of micro-RNA and DNA for determining the body fluid origin of DNA profiles. J Forensic Sci 58: 967-971. doi:10.1111/15564029.12160

Vennemann M, Koppelkamm A. 2010. mRNA profiling in forensic genetics I: possibilities and limitations. Forensic Sci Int 203: 71-75. doi:10.1016/j.forsciint.2010.07.006

Virkler K, Lednev IK. 2009. Analysis of body fluids for forensic purposes: from laboratory testing to non-destructive rapid confirmatory identification at a crime scene. Forensic Sci Int 188: 1-17. doi:10 .1016/j.forsciint.2009.02.013

Wallace SS. 2014. Base excision repair: a critical player in many games. DNA Repair (Amst) 19: 14-26. doi:10.1016/j.dnarep .2014 .03 .030
Wang Z, Zhang J, Luo H, Ye Y, Yan J, Hou Y. 2013. Screening and confirmation of microRNA markers for forensic body fluid identification. Forensic Sci Int Genet 7: 116-123. doi:10.1016/j.fsigen 2012.07.006

Wang Z, Zhou D, Cao Y, Hu Z, Zhang S, Bian Y, Hou Y, Li C. 2016. Characterization of microRNA expression profiles in blood and saliva using the lon Personal Genome Machine ${ }^{\circledR}$ System (Ion PGM ${ }^{\mathrm{TM}}$ System). Forensic Sci Int Genet 20: 140-146. doi:10.1016/j.fsigen .2015.10.008

Watanabe K, Iwashima Y, Akutsu T, Sekiguchi K, Sakurada K. 2014. Evaluation of a co-extraction method for real-time PCR-based body fluid identification and DNA typing. Leg Med (Tokyo) 16: 56-59. doi:10.1016/j.legalmed.2013.11.002

Wegman DW, Krylov SN. 2013. Direct miRNA-hybridization assays and their potential in diagnostics. TrAC Trends Anal Chem 44: 121-130. doi:10.1016/j.trac.2012.10.014

Winter J, Jung S, Keller S, Gregory RI, Diederichs S. 2009. Many roads to maturity: microRNA biogenesis pathways and their regulation. Nat Cell Biol 11: 228-234. doi:10.1038/ ncb0309-228

Zubakov D, Boersma AW, Choi Y, van Kuijk PF, Wiemer EA, Kayser M. 2010. MicroRNA markers for forensic body fluid identification obtained from microarray screening and quantitative RT-PCR confirmation. Int J Legal Med 124: 217-226. doi:10.1007/s00414009-0402-3 

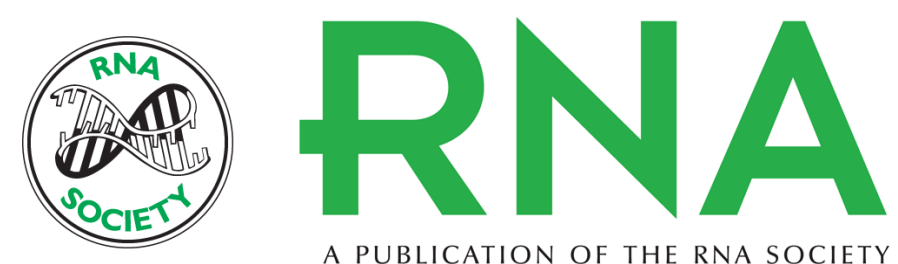

A PUBLICATION OF THE RNA SOCIETY

\title{
Potential applications of microRNA profiling to forensic investigations
}

\author{
Claire L. Glynn
}

RNA 2020 26: 1-9 originally published online October 28, 2019

Access the most recent version at doi:10.1261/rna.072173.119

References This article cites 74 articles, 4 of which can be accessed free at: http://rnajournal.cshlp.org/content/26/1/1.full.html\#ref-list-1

Creative This article is distributed exclusively by the RNA Society for the first 12 months after the Commons full-issue publication date (see http://rnajournal.cshlp.org/site/misc/terms.xhtml). After 12 License months, it is available under a Creative Commons License (Attribution-NonCommercial 4.0 International), as described at http://creativecommons.org/licenses/by-nc/4.0/.

Email Alerting Receive free email alerts when new articles cite this article - sign up in the box at the Service top right corner of the article or click here. 